\title{
EVOLUTION OF MANTLED KARST ALONG THE BLUE RIDGE- GREAT VALLEY MARGIN, USA: AN ENVIRONMENT OF SEDIMENT ACCUMULATION AND POSSIBLE PRESERVATION
}

\author{
RAZVOJ POKRITEGA KRASA NA ROBU OBMOČJA BLUE RIDGE - \\ GREAT VALLEY, ZDA: OKOLJA AKUMULACIJE IN OHRANJANJA \\ SEDIMENTOV
}

\author{
Todd GROTE ${ }^{1}$
}

\begin{abstract}
UDC 551.435.8:551.3.051(292.77)

Todd Grote: Evolution of Mantled Karst Along the Blue RidgeGreat Valley Margin, USA: An Environment of Sediment Accumulation and Possible Preservation

The Appalachian landscape provides an excellent opportunity to examine an environment that promotes sediment subsidence, accumulation and possible preservation: mantled karst. Mantled karst exists along the Blue Ridge-Great Valley margin from south-central Pennsylvania to central Virginia. Topographically, the mantled karst contains low-relief irregular topography with abundant surface depressions, some of which contain ponds, and in places lacks continual surface drainage and springs. Sand and gravel quarries along the valley margin expose predominantly stream flow, hyperconcentrated flow, debris flow and hillslope (colluvial) deposits that mantle karstic Paleozoic bedrock and carbonate residuum. Unconformable and sometimes erosive contacts between carbonate residuum and clastic sediments, and soft-sediment deformation features have been observed within exposures suggesting subsidence into accumulation and/or preservation space created by geochemical dissolution and collapse that continues today. The likelihood of long-term survival in the geological record is dependent upon the relationship between the subsiding sediment and geomorphic base level. The Blue RidgeGreat Valley mantled karst likely contains both short-term accumulation space that is closer to geomorphic base level, thus more prone to removal by fluvial processes, and preservation space, which occurs well below geomorphic base level, where sedimentary sequences may be stored for prolonged periods of time. Ultimately, both accumulation and preservation spaces can provide insight into depositional processes, landscapes and possibly paleoenvironmental conditions, but the geologic record becomes more distorted and fragmented further back into deep time and as this landscape evolves into the future.

Key words: karst, sedimentary environments, subsidence, preservation potential, landscape evolution.
\end{abstract}

\footnotetext{
${ }^{1}$ Geoscience Program, School of Natural Sciences, Indiana University Southeast, New Albany, Indiana, USA, e-mail: tdgrote@ius.edu
}

Received/Prejeto: 25.05.2019

\author{
Izvleček \\ UDK 551.435.8:551.3.051(292.77) \\ Todd Grote: Razvoj pokritega krasa na robu območja Blue \\ Ridge - Great Valley, ZDA: okolja akumulacije in ohranjanja \\ sedimentov
}

Pokriti kras Apalačev nudi izjemne možnosti preučevanja odlaganja, akumulacije in ohranjanja sedimentov. Za pokriti kras na robu območja Blue Ridge - Great Valley med južno-osrednjo Pensilvanijo in osrednjo Virginijo so značilna topografsko razgibana nižavja s številnimi depresijami, ki so lahko tudi ojezerjene, površinski odtok pa je ponekod nepovezan. Kamnolomi peska in grušča vzdolž roba doline razkrivajo različne fluvialne in pobočne sedimente, ki pokrivajo zakrasele paleozojske karbonate in njihov reziduum. Nekonformni in erozijski stiki med karbonatnim reziduumom in klastičnimi sedimenti ter deformacijske oblike v mehkih sedimentih kažejo na akumulacijo in ohranjanje sedimentov v kraških prostorih. Časovna stabilnost sedimentov je odvisna tudi od položaja ugrezanja sedimentov glede na erozijski nivo: prostori akumulacije so blizu erozijskega nivoja in zato podvrženi fluvialnemu odnašanju, prostori ohranjanja pa so pod erozijskim nivojem, zato so tam sedimentna zaporedja ohranjena precej dlje. Preučevanje prostorov akumulacije in prostorov ohranjanja nam omogoča boljše razumevaje razvoja pokrajine in sedimentacijskih procesov v njej. Starejši zapisi so slabše ohranjeni in bolj razdrobljeni.

Ključne besede: kras, sedimentacijska okolja, ugrezanje, potencial ohranjanja sedimentov, razvoj površja. 


\section{INTRODUCTION}

Sediment deposition, subsidence, and survival into local or regional preservation space (sensu Blum \& Tornqvist 2000) in continental settings are of interest to sedimentologists, stratigraphers and geomorphologists devoted to understanding sedimentary/stratigraphic architecture, and reconstructing paleoenvironmental and landscape conditions. Blum and Tornqvist (2000) preferred the use of "preservation space" and "accumulation space" over "accommodation space", which is commonly used in sequence stratigraphy, when discussing the long-term evolution of fluvial systems. They note that accumulation space represents "...the volume of space that can be filled within present process regimes, and is fundamentally governed by the relationship between stream power and sediment load, and how this changes in response to geomorphic base level". The usage of the term preservation space in fluvial settings implies that subsidence allows sediments to sink into the subsurface below the limit of stream downcutting and erosion - in essence geomorphic base level (Blum \& Tornqvist 2000; Weissmann et al. 2002). Clearly there is a relationship between accumulation space and preservation space in that if stratigraphic sequences that fill accumulation space do not subside below geomorphic base level, then the chance of preservation within the geologic record is low (Weissmann et al. 2002).

The concepts of fluvial accumulation and preservation spaces can also be applied to karst landscapes, but generally on a more localized scale. The hydrology of karst landscapes allows for surface water to infiltrate porous soils and sediments and enter a complex groundwater system with highly variable, and sometimes unpre- dictable, flow routes. Karst accumulation and preservation space in classic limestone (carbonate) terrain is the result of geochemical dissolution by groundwater along the network of subsurface flow paths, and subsidence and collapse of bedrock, which creates voids in the host bedrock that can later be filled by unconsolidated sediments in either syndepositional or post-depositional environments (e.g., Whittecar \& Duffy 2000; Sevon 2001; Grote 2006; Pazzaglia et al. 2006, Stepišnik et al. 2007; Southworth et al. 2009; Pazzaglia 2014; Grote 2017). Accumulation and preservation of unconsolidated sediments also occurs in evaporite karst landscapes by dissolution and collapse processes that are similar to those that occur in carbonate terrain (e.g., Gustavson 1986; Benito et al. 2000; Luzon et al. 2008; Benito et al. 2010; Luzon et al. 2012; Soriano et al. 2012).

Karst preservation space may be spatially limited to individual sinkholes (e.g., Luzon et al. 2008; Sauro et al. 2009; Shunk et al. 2009; Soriano et al. 2012), or as regionally extensive as solutional troughs (e.g., Gustavson 1986; Chichester 1996; Grote 2006; Pazzaglia et al. 2006; Stepišnik et al. 2007; Southworth et al. 2009; Benito et al. 2010; Pazzaglia 2014; Grote 2017). Nonetheless, in some landscapes the filling of karst preservation space has allowed for site-specific preservation of exceptionally old stratigraphic sequences in eastern North America (e.g., Late Cretaceous - Pond Bank, southern Pennsylvania (Pierce 1965; Tschudy 1965), Late Miocene - Gray's Fossil Site, northeastern Tennessee (Shunk et al. 2006) and Early Pliocene - Pipe Creek Sinkhole, Indiana (Shunk et al. 2009).

\section{PURPOSE AND SCOPE}

This paper will discuss the evolution of mantled karst in the context of sediment subsidence, accumulation and possible preservation within karst-produced subsurface voids using the Blue Ridge-Great Valley margin in the Appalachians of the Eastern United States as an example (Fig. 1). Field studies of deep sand-and-gravel quarries and other exposures in Pennsylvania and Maryland, surficial geologic mapping, analysis of high-resolution LiDAR (light detection and ranging) digital imagery, and a synthesis of geologic and hydrogeologic information are used to discuss the topographic characteristics, and the sedimentologic and stratigraphic nature of sediment fill (the clastic mantle) along the Blue Ridge-Great Valley margin. Secondly, the accumulation and potential for long-term preservation of sediment which may contain paleoenvironmental archives will be discussed in relation to geomorphic base level and landscape evolution. 


\section{METHODS}

Sedimentologic characteristics and stratigraphic relationships visible in three deep sand-and-gravel pits in south-central Pennsylvania were documented periodically from 2002 until 2010 as new pit faces were exposed, and at times deepened, and as time allowed. All sedimentologic descriptions followed the terminology of Miall (1996). The three pits are some of the only deep excavations that provide a glimpse into the mantled karst environment along the Blue Ridge-Great Valley margin in south-central Pennsylvania. Other deep pits exposing clastic sediments overlying karstified bedrock occur along the Blue Ridge-Great Valley margin in central Vir- ginia and have been reported on by other investigators (e.g., Kochel 1990; Whittecar \& Duffy 2000). The main focus of field work in this study was to identify depositional processes responsible for creating the clastic mantle that buries karstified bedrock along the Blue RidgeGreat Valley margin, and also to examine syn- and postdepositional modification to the sedimentary sequence. To supplement sand-and-gravel pit observations which occurred from 2002 until 2010, information from other previously visited shallow, and often ephemeral, exposures of clastic sediments along the Northern Blue Ridge margin in south-central Pennsylvania and central Mary-

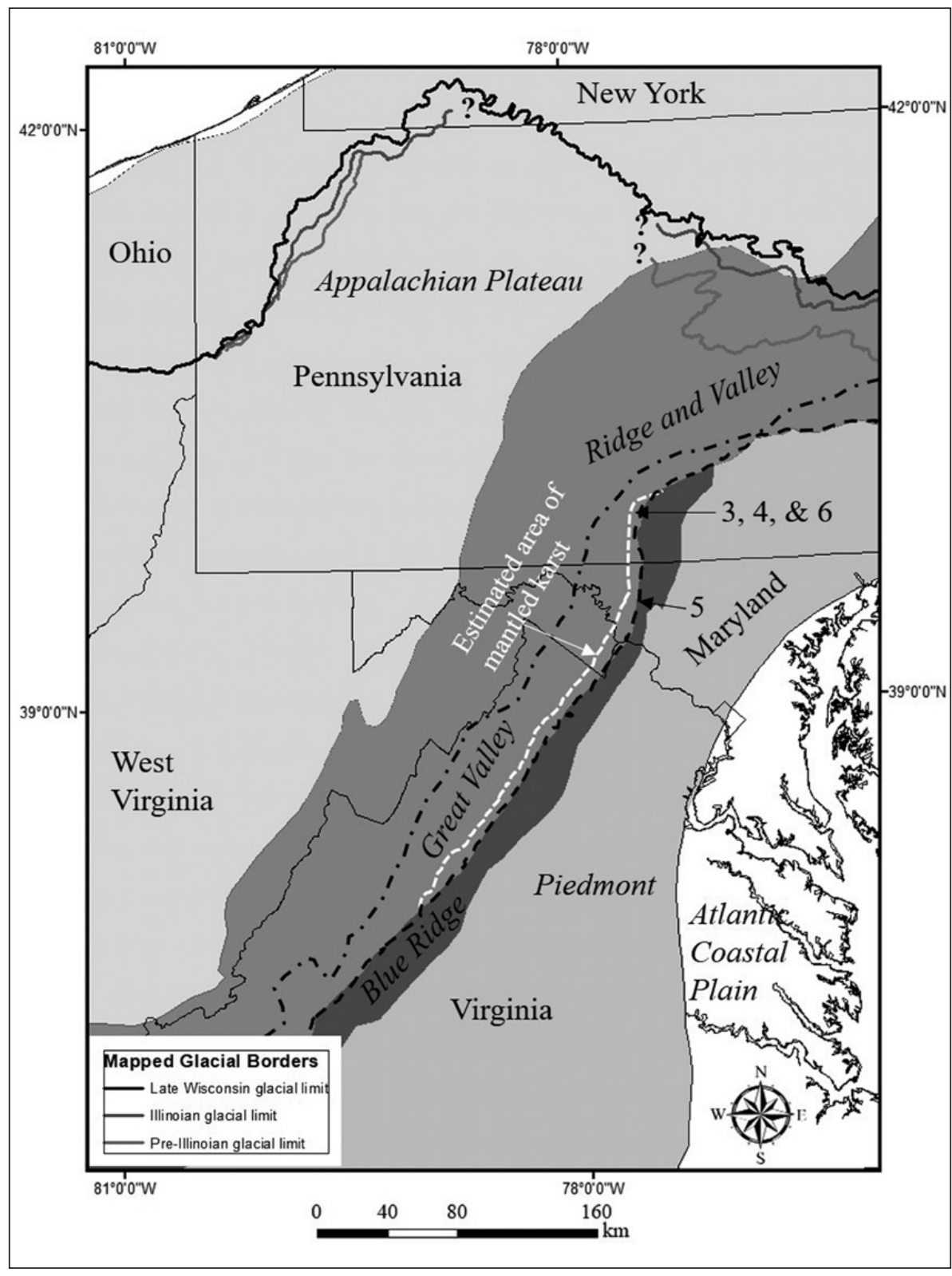

Fig. 1: Approximate boundary (dashed white line) of the mantled karst along the Blue Ridge-Great Valley margin in the Appalachian region of Eastern North America. The Great Valley is a subsection of the Ridge and Valley Province that abuts the Blue Ridge highlands and is delineated by the black dashed lines. The location of Figs. 3, 4, 5 \& 6 are shown by number as such. Question marks "?" denote unknown glacial margin positions. 
land by the author were synthesized (Grote \& Kite 2004; Grote 2006; Grote \& Kite 2006). Water well information for the Blue Ridge-Great Valley margin of Pennsylvania and Maryland was also examined as part of these studies to gain a better understanding of the geometry of the surficial deposits mantling the buried bedrock surface.
Finally, the release of high-resolution LiDAR imagery starting in 2005 for the south-central Pennsylvania study area has revealed new information on the complex topography and impact of sub-surface karst development along the Blue Ridge-Great Valley margin and is incorporated into this study.

\section{STUDY AREA}

Fluviokarst is the most abundant type of karst landscape found throughout the Appalachian Region of the Eastern United States (White 2009). However, along the eastern border of the Great Valley section of the Ridge and Valley Physiographic Province, karstified Early Paleozoic bedrock is buried by surficial deposits shed from the adjacent Blue Ridge uplands (hereafter referred to as the Blue Ridge-Great Valley margin) from south-central Pennsylvania southward into central Virginia (Figs. 1 \& 2). The Blue Ridge-Great Valley margin is better described as mantled karst, which can be defined as "covered with allochthonous rock or sediment. It is part of the contemporary landscape, and older than its cover" (White 1988). The definition is a slight modification of the original terminology of simply "covered karst" used by Quinlan (1967). The Blue Ridge-Great Valley margin mantled karst could also be considered a type of contact karst in the usage of Stepišnik et al. (2007) because acidic surface waters flow from the resistant meta-sedimentary, meta-igneous rocks and metamorphic uplands of the Blue Ridge onto the unconsolidated clastic sediments along the mountain front where the water infiltrates into the underlying carbonate rocks of the Great Valley (e.g., Becher \& Root 1981; Grote 2001; Sevon 2001; Grote 2006; Pazzaglia et al. 2006, Pazzaglia 2014). The term mantled karst is preferred in this study because of the extensive blanket of clastic sediments which nearly continuously masks karstified bedrock along the Blue Ridge-Great Valley margin in the study area.

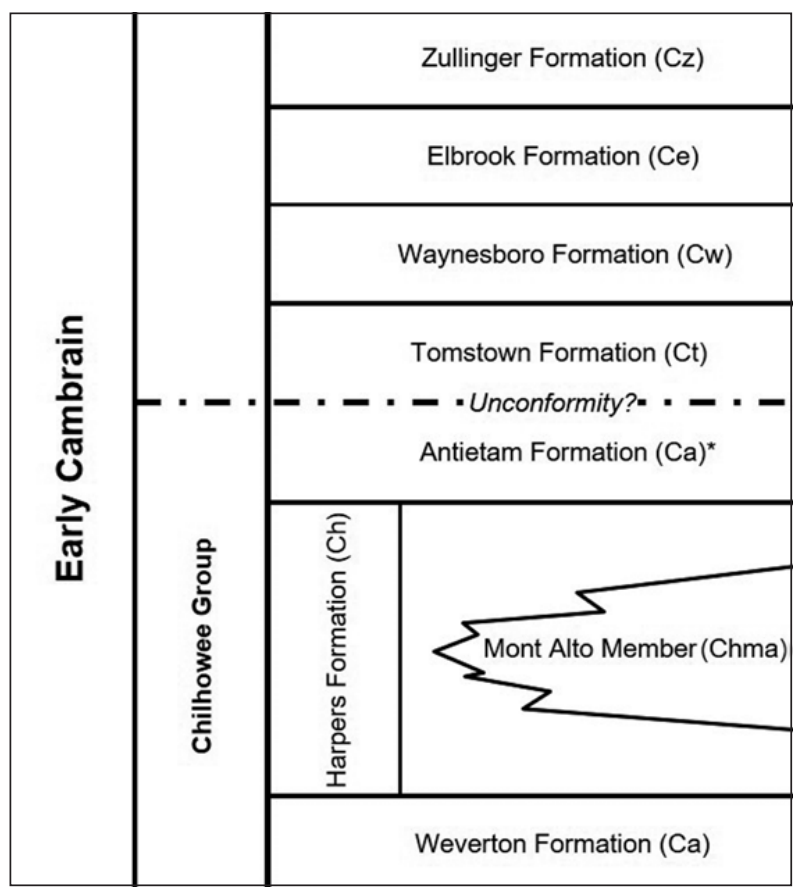

Fig. 2: Bedrock geologic framework for the Blue Ridge-Great Valley margin in the study area. The Chilhowee Group rocks are metasedimentary and metamorphic rocks of the Blue Ridge, whereas the Tomstown through Zullinger formations are carbonate strata of the Great Valley. All of the Great Valley units are karstfied to varying degrees, with the Tomstown Formation being the most developed. ${ }^{*}$ In Virginia, the Shady Formation is stratigraphically equivalent to the Tomstown Formation which is used in Pennsylvania and Maryland. Data compiled from Gathright et al. (1977), Becher \& Root (1981), Duigon (2001) and Southworth et al. (2009).

\section{TOPOGRAPHY OF BLUE RIDGE-GREAT VALLEY MANTLED KARST}

The mantled karst along the Blue Ridge-Great Valley margin in Pennsylvania and Maryland is characterized by low-relief irregular, undulating topography that occurs in a belt up to several kilometers or more wide that is believed to reflect subsidence and collapse of surficial deposits into the underlying irregularly karstified bedrock
(Fig. 3). The topographic form of the surficial deposits resembles a series of coalescing, multi-aged (e.g., Whittecar \& Duffy 2000; Grote 2006) alluvial fans (Fig. 4). The amount of relief present within the Blue Ridge-Great Valley margin is likely controlled to some extent by the age and thickness of the surficial mantle, and also the solubil- 
ity of the underlying bedrock. Temporary (vernal), and in some cases older late Wisconsin-aged (Watts 1979; Delano et al. 2002), ponds occupy some surface depressions (see Fig. 3). Losing and gaining streams, numerous springs and dry valleys are also present throughout the landscape indicating a complex groundwater-surface water hydrogeomorphic system.

\section{SEDIMENTOLOGY OF THE CLASTIC MANTLE}

Deep sand-and-gravel quarry exposures exist within south-central Pennsylvania and numerous other shallow, natural or artificial exposures reveal a variety of transported clastic sediments, carbonate residuum, and sparse bedrock outcrops make up the surficial geology of the Blue Ridge-Great Valley margin (Figs. 4 \& 5). The clastic materials, primarily quartzite and metasandstones, of Blue Ridge provenance were deposited along the Blue Ridge-Great Valley margin by a variety of depositional processes. Sedimentologic characteristics of observed exposures close to the mountain front suggest that debris flows and hillslope colluvial processes delivered sandy and gravelly, angular to sub-rounded diamicton to the proximal fan environment (Figs. $4 \& 5$ ).

Debris flow and colluvial deposits interfinger with alluvial and hyperconcentrated flow deposits near stream channels. Grote (2006) and Grote and Kite (2006) show that alluvial deposits become more abundant, and even dominate, in the medial and distal fan environments. Alluvial deposits generally consist of sub-rounded to rounded, sand and gravel. Some gravel beds are weakly to moderately imbricated and stratified, but many are

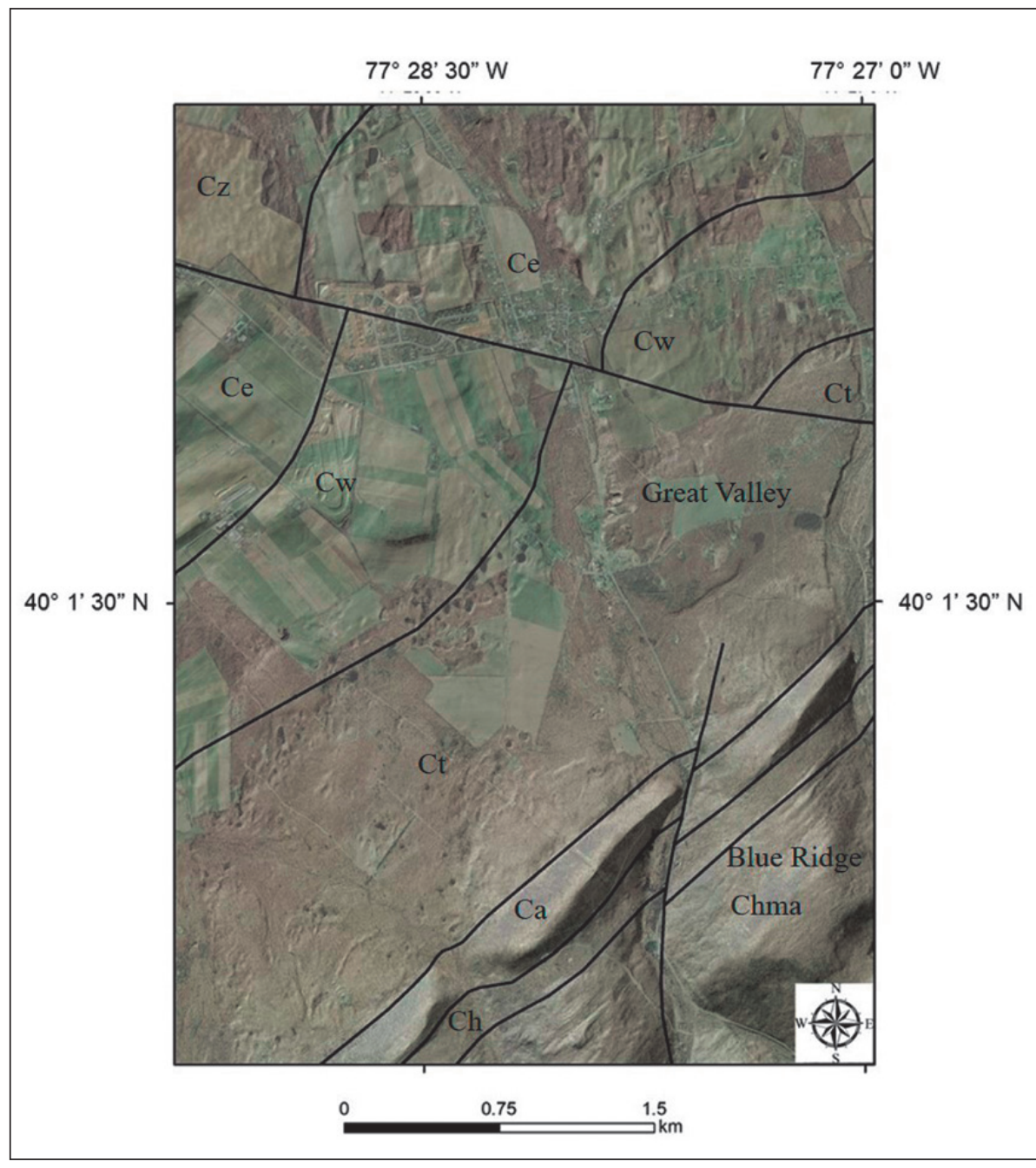

Fig. 3: Composite high-resolution light detection and ranging ( $\mathrm{Li}$ $D A R$ ) digital elevation model and semi-transparent aerial orthophotography showing numerous sinkholes and other karst features along the Blue Ridge-Great Valley margin in south-central Pennsylvania (See Fig. 1 for location and Fig. 2 for geologic formation abbreviations). Note area of high sinkhole concentration (dark circular and irregular shapes) at the contact between the Tomstown (Ct) and Waynesboro (Cw) formations near center of image. Digital imagery and bedrock geology files obtained from https://www.pasda.psu.edu/. The solid white lines denote faults. Dashed white line denotes the limit of mantled karst. 


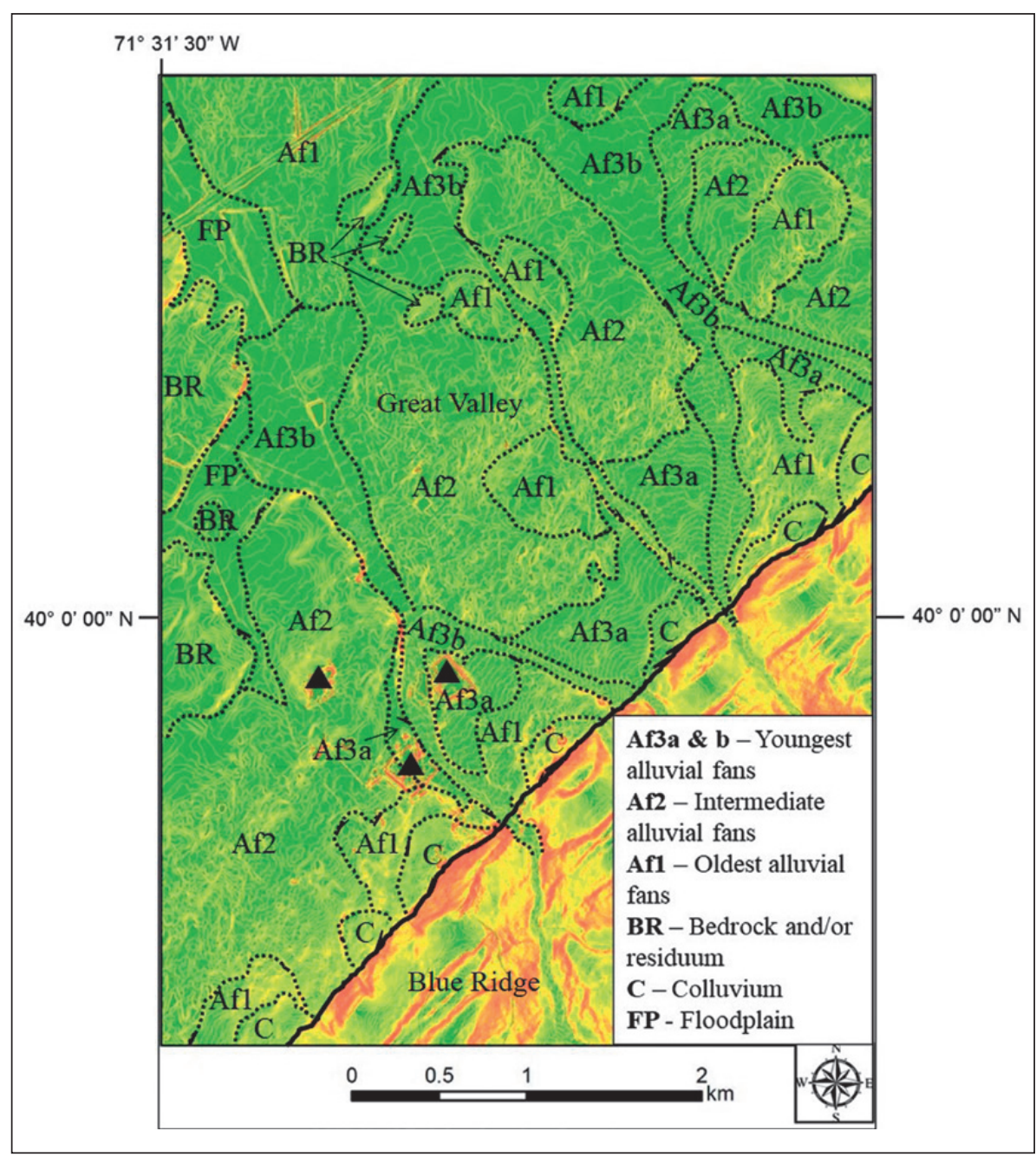

Fig. 4: LiDAR-derived topography and slope-steepness image depicting the surficial geology of the clastic mantle of a portion of the study area (see Fig. 1 for location). Green colors denote gentle slopes and red denotes steep slopes. The very irregular and erratic topographic contour lines (light yellow lines) reflect the sediment subsidence and the underlying karstfied bedrock. Black triangles represent deep sand-andgravel quarries used to interpret the subsurface stratigraphy of the alluvial fans. LiDAR elevation imagery downloaded from https://www. pasda.psu.edu/. Surficial geology adapted and modified from Grote (2006) and Grote \& Kite (2006).

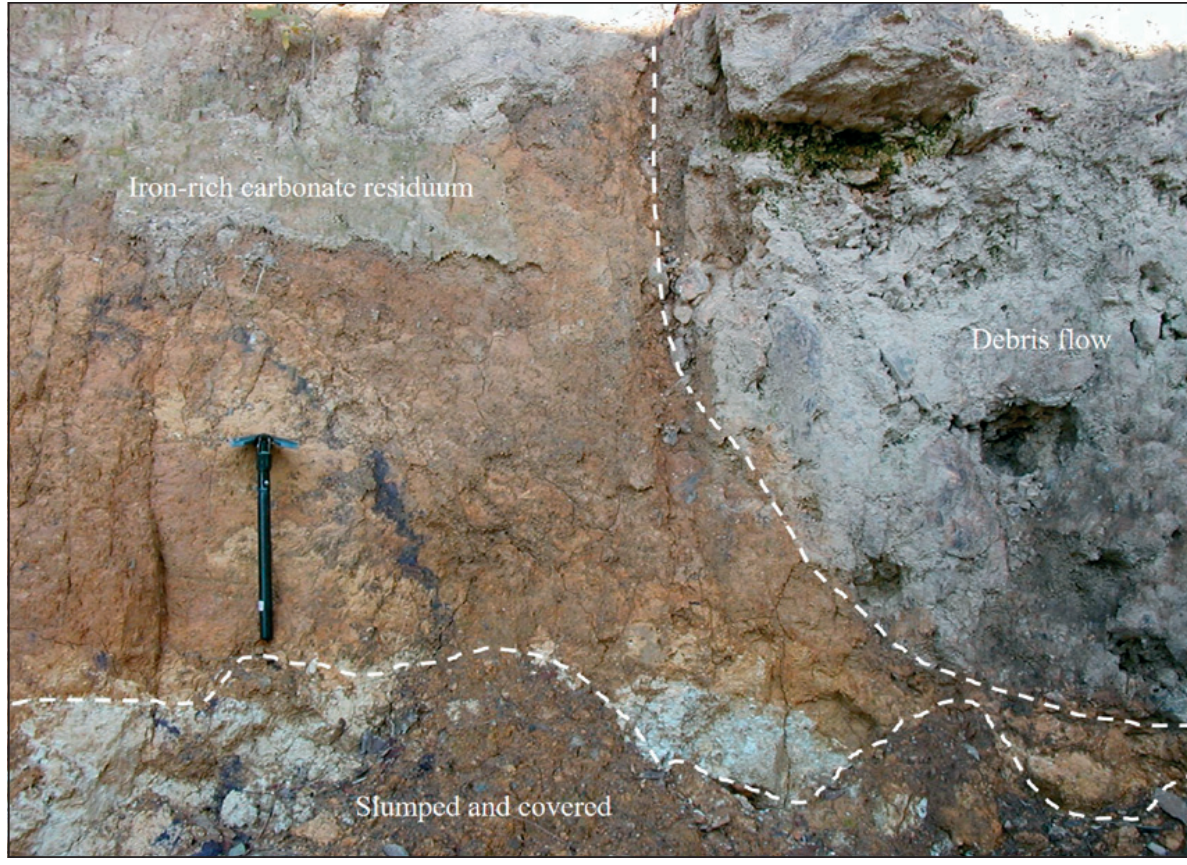

Fig. 5: Example of clastic sediments of Blue Ridge provenance eroding through or subsiding into karst accumulation space (See Fig. 1 for location). In this case the carbonate bedrock (presumably of the Tomstown Formation) has been chemically weathered to an iron-rich residual deposit. Entrenching tool for scale. 
massive, clast-supported or matrix-supported diamictons (Fig. 6a \& 6b). Sand units are typically less than 1.0 $m$ thick and are either massive or horizontally stratified (Fig. 6b). Some sand units contain weak planar and trough cross-bedding, ripple marks and climbing ripples. Sand and gravel pit observations indicates that the majority of the clastic consists of alluvial/fluvial deposits, which show numerous cut-and-fill, and stacked channel sequences indicative of an active fluvial system. Deep weathering and numerous paleosols have also been observed in the pits, which suggest phases of landscape stability (e.g., Grote 2006; Pazzaglia 2014; Grote 2017).

The effects of subsidence into subsurface karst features are locally manifest where clastic sediments are in unconformable and sometimes erosive contact with carbonate residuum (see Fig. 5), and where soft sediment deformation that includes bedding dipping towards the mountain front (Fig. 6b), slumping, normal and listric faults, antiform structures and deformed/disruptive bedding (Fig. 6c). Evidence of buried sinkhole ponds may also be present as isolated silty and clayey pods, and laminated lenses observed in one sand-and-gravel pit, but a definitive origin is inconclusive. Although not directly investigated during this study, Sevon (2001) also suggests that the presence of clastic dikes within the alluvial fan stratigraphy is further evidence of subsidence into subsurface karst features.

\section{STRATIGRAPHY AND EVOLUTION OF BLUE RIDGE-GREAT VALLEY MANTLED KARST}

Chemical weathering and mechanical collapse of carbonate bedrock appears to have been a continual process predating the Quaternary Period, and possibly beginning as far back as the Mesozoic (Pierce 1965; Tschudy 1965; Bikerman et al. 1999; Sevon 2001; Grote 2006; Pazzaglia et al. 2006; Pazzaglia 2014; Grote 2017). Two cosmogenic burial age determinations using the ${ }^{26} \mathrm{Al} /{ }^{10} \mathrm{Be}$ technique yielded ages of 6.9 Ma and 7.9 Ma for clastic alluvial fan sediments sampled between 15-20 meters below the ground surface in central Virginia (Heller et al. 2014).
Bikerman et al. (1999) used K-Ar absolute dating methods on manganese-bearing residual deposits along the Blue Ridge margin in south-central Pennsylvania and found the ores primarily formed between the Late Paleocene/early Eocene and the Miocene (ages ranged from $58+/-5 \mathrm{Ma}$ to $6+/-0.5 \mathrm{Ma}$ ). One of the K-Ar samples yielded a much older Mesozoic (Triassic) age as well. Palynomorphs found within lignitic clay in south-central Pennsylvania yielded a late Cretaceous age (Pierce 1965; Tschudy 1965). When taken together, the ages suggest

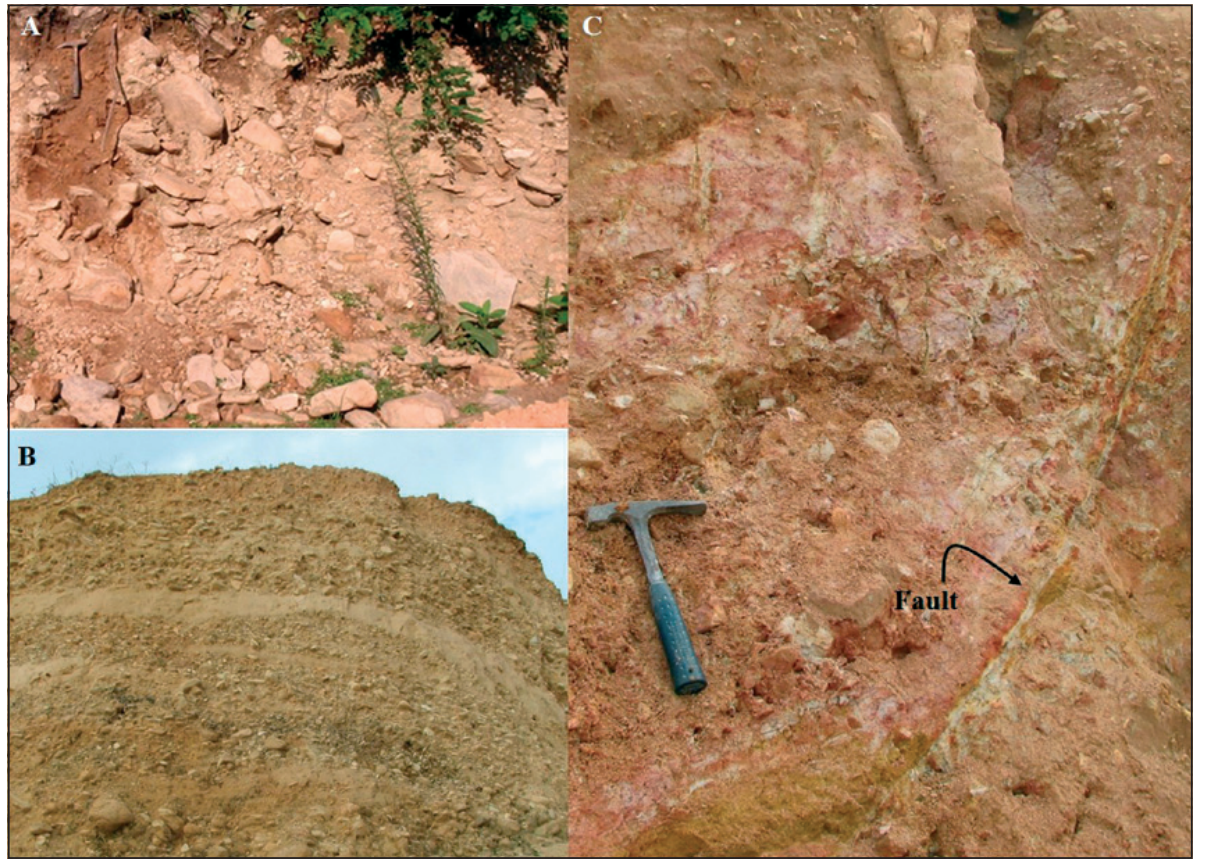

Fig. 6: Example sediment features exposed in the sand and gravel pits. 6 a shows a generally clastsupported diamicton with weak zones of imbrication. Hammer in upper left corner for scale. $6 b$ is a typically interbedded alluvial/ fluvial sand (light colored) and gravel (darker colored) sequence. The gravel units again show weak imbrication generally toward the left and into the photo. Note however that the sequence dips slightly to the right and into the photo, which is interpreted to be caused by subsidence into karst accommodation space. Height of the exposure is approximately 4 meters. $4 c$ shows sediment slumping along a small, localized listric fault. Slumping motion along fault is down and to the left of the photo. Hammer for scale. 
that bedrock karstification has been a long-term process dating to the late Cretaceous, possibly as old as the Triassic, and this karstification has allowed for clastic sediments shed from the Blue Ridge to subside, accumulate and possibly be stored for an extended period of time within deep preservation space.

The spatially and temporally extensive nature of karstification of the Tomstown Formation and the stratigraphically equivalent Shady Formation allows for the subsidence, accumulation and in many cases preservation of thick sequences of clastic sediment (e.g Whittecar \& Duffy 2000; Sevon 2001; Grote 2006; Pazzaglia et al. 2006; Southworth et al. 2009; Pazzaglia 2014). Data presented in this study and by others (e.g., Kochel 1990; Whittecar \& Duffy 2000; Sevon 2001; Grote 2006; Southworth et al. 2009; Grote 2017) demonstrates that clastic sediments shed from the Blue Ridge uplands largely by tractive transport within stream channels, by hyperconcentrated flows, by debris flows and by hillslope colluviation, coalesces and spreads out into the Great Valley to form the clastic mantle, and where present, fill karst depressions and voids. Carbonate residuum produced by the in-situ dissolution of bedrock also comprises a portion of the mantled karst landscape (Pierce 1965; Whittecar \& Duffy 2000; Sevon 2001; Grote \& Kite 2004; Grote 2006; Grote \& Kite 2006; Pazzaglia 2014). In some cases, water wells and other subsurface exposures indicate that carbonate bedrock is in places mantled by over $100 \mathrm{~m}$ of carbonate residuum and clastic sediment of Blue Ridge provenance, but values of $30 \mathrm{~m}$ or less are much more common (Gathright et al. 1977; Becher \& Root 1981; Chichester 1996; Duigon 2001; Sevon 1994; Sevon 2001; Southworth et al. 2009). In general however, the thickest surficial deposits appear to be located nearest the mountain front where they overlie the Tomstown and Shady formations (Figs. 3 \& 4), and around drainageways, which then thin with increasing distance into the Great Valley (Gathright et al. 1977; Becher \& Root 1981; Duigon 2001; Sevon 2001; Grote \& Kite 2004; Grote \& Kite 2006; Southworth et al. 2009; Pazzaglia 2014; Grote 2017). Chichester (1996) suggested that the extensive karstfication of the Tomstown Formation in Pennsylvania may be considered a deep solutional trough. The advanced degree of karstfication of the Tomstown and Shady formations is due to acidic streamflow originating on the Blue Ridge hillslopes that enters the groundwater system through the generally porous clastic mantle and into the groundwater system and geochemically dissolve the underlying carbonate bedrock (Becher \& Root 1981; Chichester 1996; Grote 2001; Sevon 2001; Grote \& Woltemade 2002; Grote 2006; Pazzaglia et al. 2006; Pazzaglia 2014). More isolated and/or limited areas of sediment subsidence into subsurface voids occur away from the mountain front where deep karstification is less extensive (e.g., the Waynesboro and Elbrook formations shown in Figs. $2 \& 3$ ) and the amount of sediment delivered from the Blue Ridge is far less due to increased transport distance.

\section{SEDIMENT ACCUMULATION AND PRESERVATION IN MANTLED KARST LANDSCAPES}

Mantled karst landscapes have the ability to accumulate and preserve sedimentary sequences useful to sedimentologists, stratigraphers and geomorphologists. Field observations presented in this study and by the work of numerous others have identified ample evidence of soft-sediment deformation including convolute bedding, deformed beds, beds dipping towards the mountain front, thus contrary to paleoflow direction, small-scale folds and in a few places, weakly expressed normal and listric faults (Whittecar \& Duffy 2000; Sevon 2001; Grote 2006; Grote \& Kite 2006; Pazzaglia 2014; Grote 2017). These features are interpreted to represent the subsidence of the clastic mantle into karstic bedrock voids which represent accumulation and preservation space. Furthermore, clastic dikes that occur throughout the sand-and-gravel quarries in south-central Pennsylvania and may represent additional evidence for karst-related subsidence of the clastic mantle (e.g., Sevon 1994; Sevon 2001).

The question to now be addressed is how long will the sedimentary sequences be preserved? The answer is - it depends on how deeply buried the sedimentary sequence is relative to geomorphic base level, thus how effective geomorphic processes are at removing the deposits from the landscape. Mantled karst landscapes have a modest chance of sedimentary sequences persisting into deep time due to the, in general, slow, long-term incision rates of rivers into bedrock (e.g., Pazzaglia 2014), the complexity of surface water-groundwater interactions that diminishes the erosive potential of streams, and the possibility that at least some of the sediment stored will be below geomorphic base level (Pazzaglia 2014; Grote 2017). In that sense, it is probably more appropriate to suggest that mantled karst landscapes have 
some combination of accumulation space where sedimentary sequences are stored over short to medium time scales and are more susceptible to removal, and preservation space where sedimentary sequences are stored for prolonged periods of time well below geomorphic base level. Indeed, the Great Valley-Blue Ridge margin seemingly contains both short-term accumulation space and longer-term preservation space (Fig. 7). For example, the surficial geology of the Blue Ridge-Great Valley margin consists of a patchwork of alluvial fan deposits of numerous ages (Fig. 4), which are also preserved within the subsurface stratigraphy (Whittecar \& Duffy 2000; Sevon 2001; Grote 2006; Pazzaglia et al. 2006; Southworth et al. 2009; Pazzaglia 2014; Grote 2017). At the surface, stream incision and lateral migration of stream channels on the alluvial apron are slowly re-working and removing sediment within the valley that is above geomorphic base level (see Figs. 4 \& 7), thus removing it from the stratigraphic record (Whittecar \& Duffy 2000; Grote 2006; Pazzaglia et al. 2006; Pazzaglia 2014; Grote 2017). However, the infiltration and diversion of surface water flowing from the Blue Ridge hillslopes into the clastic mantle and karstified bedrock system plays a role in the preservation of sedimentary sequences because of a loss of stream power and the associated erosion potential (Grote 2006; Grote 2017). In addition, this acidic water contrib- utes to the dissolution of buried carbonate bedrock. Near the mountain front where surface water is being lost to subsurface flow, deep bedrock dissolution and karstification have allowed some of the sedimentary sequences to be lowered well below geomorphic base level where they may be preserved for an extended period of time (Fig. 7), as evidenced by late Cretaceous lignitic clays underlying the alluvial apron (Pierce 1965; Whittecar \& Duffy 2000; Pazzaglia 2014; Grote 2017).

Although soft-sediment deformation and subsidence have impacted sedimentary sequences preserved within the Blue Ridge-Great Valley mantled karst landscape, the deposits still provide insight into depositional processes, landscapes and possibly paleoenvironmental conditions. Sinkholes within the Blue Ridge-Great Valley margin mantled karst have provided paleoecological and landscape information (e.g., Pierce 1965; Tschudy 1965; Watts 1979; Delano et al. 2002), and accumulation and/or preservation space contains a long-term record of landscape evolution, including phases of landscape instability, hillslope erosion and alluvial fan sedimentation, and phases of landscape stability, deep geochemical weathering and soil formation (Whittecar \& Duffy 2000; Sevon 2001; Grote 2006; Pazzaglia et al. 2006; Southworth et al. 2009; Pazzaglia 2014; Grote 2017).

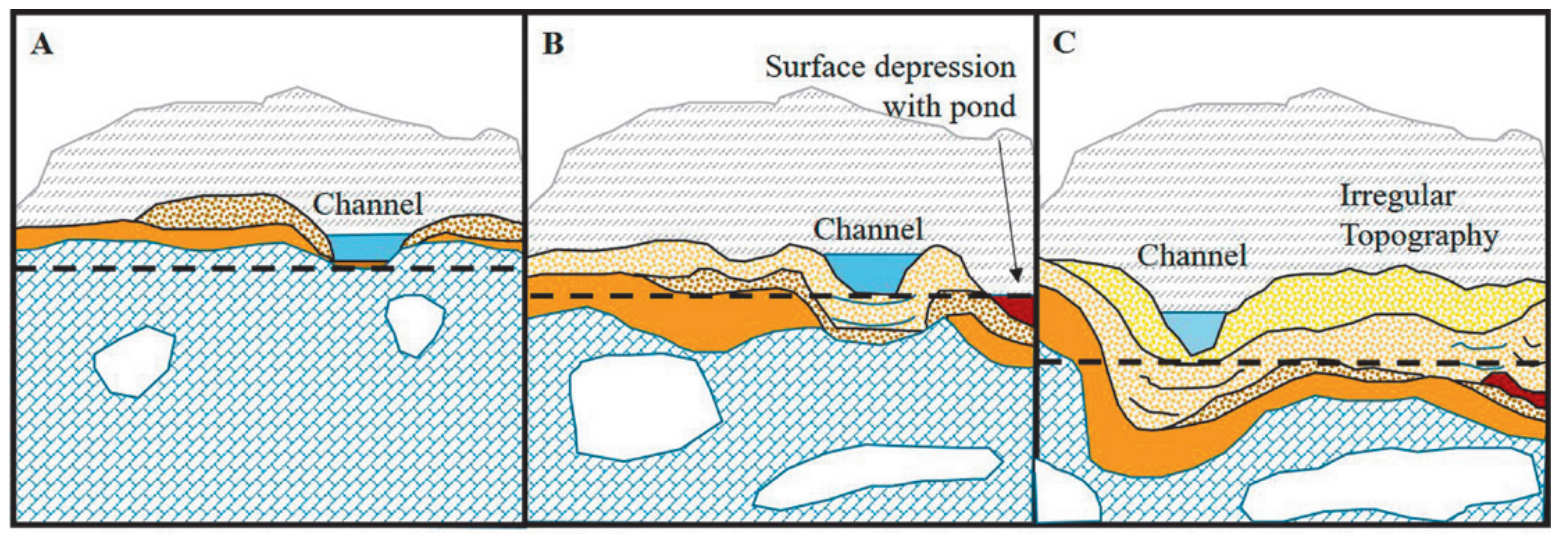

Af1 国 Af2 图 Af3 $\square$ Carbonate residuum 图 Carbonate bedrock

Dissolutional void - - -Geomorphic base level

Fig. 7: Schematic model of mantled karst development along the Blue Ridge-Great Valley margin. A-C represent generalized cross-sectional representations of alluvial fan deposition, stream erosion, bedrock karstfication and sediment subsidence through time. At time A, there is no clastic sediment below geomorphic base level, thus a low chance of subsurface preservation. Time B shows that some sediment, both clastic and residual, has been lowered below geomorphic base level. Time $C$ shows the continual evolution of the mantled karst landscape due to chemical dissolution of carbonate bedrock and episodic clastic sedimentation. At this stage some sediments are well below geomorphic base level and are stored in deep preservation space, whereas sediment nearer base level would be stored in accumulation space. Streamflow is out of the figure and away from the Blue Ridge metasedimentary and metamorphic rocks. 


\section{CONCLUSION}

As demonstrated in this paper, mantled karst along the Blue Ridge-Great Valley margin, in the Appalachian region of the eastern United States demonstrates the complex interplay of bedrock dissolution and karstification, and episodic clastic sedimentation. The irregular topography of the clastic mantle, unconformable and sometimes erosive contacts between carbonate residuum and clastic sediments, and subsurface soft-sediment deformation features are evidence that the clastic mantle is slowly subsiding into karstified bedrock. The likelihood of long-term survival in the geological record is dependent upon the relationship between the subsiding sediment and geomorphic base level. The Blue Ridge-Great Valley mantled karst likely contains both short-term accumulation space that is closer to geomorphic base level, thus more prone to removal by fluvial processes, and preservation space, which occurs well below geomorphic base level, where sedimentary sequences may be stored for prolonged periods of time. Ultimately, both accumulation and preservation spaces can provide insight into valley margin depositional processes, phases of landscape stability and instability, and possibly paleoenvironmental conditions, but the geologic record becomes more distorted and fragmented further back into deep time and as this landscape evolves into the future. Data presented in this paper also provides a model of landscape evolution which may stimulate searches for additional deeply buried, and potentially old deposits that may provide insight into ancient paleoecology, paleoclimate and landscapes along the Blue Ridge-Great Valley margin, and in other mantled karst setting worldwide.

\section{ACKNOWLEDGEMENTS}

Project funding was partially provided by the U.S. Geological Survey EDMAP Program and graduate student research grants by the Geological Society of America and the Southeastern Section of the Geological Society of America. Valley Quarries of Chambersburg graciously allowed access to their sand and gravel pits. Numerous landowners also permitted access to their properties and are gratefully thanked. Comments and suggestions from 2 reviewers greatly improved the final version of the manuscript and they are wholeheartedly thanked.

\section{REFERENCES}

Becher, A.E. \& S.I. Root, 1981: Groundwater and geology of the Cumberland Valley, Cumberland County, Pennsylvania.- Pennsylvania Geological Survey, $4^{\text {th }}$ Series, Water Resource Report 50, pp. 114.

Benito, G., Perez-Gonzalez, A., Gutierrez, F. \& M.J. Machado, 2000: River response to Quaternary subsidence due to evaporite solution (Gallego River, Ebro Basin, Spain).- Geomorphology, 22, 243-263. DOI: 10.1016/S0169-555X(97)00088-3

Benito, G., Sancho, C., Pena, J.L., Machado, M.J. \& E.J. Rhodes, 2010: Large-scale karst subsidence and accelerated fluvial aggradation during MIS6 in NE Spain: climate and paleohydrological implications.Quaternary Science Reviews, 29, 2694-2704. DOI: 10.1016/j.quascirev.2010.06.020

Bikerman, M., Myers, T., Prout, A.A. \& R.C. Smith, 1999: Testing the feasibility of K-Ar Dating of Pennsylvania cryptomelanes [potassium manganese oxides].-
Journal of the Pennsylvania Academy of Science, 72, 109-114.

Blum, M.D. \& T.E. Tornqvist, 2000: Fluvial response to climate and sea-level change: a review and look forward.- Sedimentology, 47, 2-48. DOI: 10.1046/j.1365-3091.2000.00008.x

Chichester, D.C., 1996: Hydrogeology of, and simulation of ground-water flow in, a mantled carbonate-rock system, Cumberland Valley, Pennsylvania.- U.S. Geological Survey Water-Resources Investigations Report 94-4090, pp. 39. DOI: 10.3133/wri944090

Delano, H.L., Miller, N.G. \& N. Potter Jr., 2002: Plant fossil evidence for Late Pleistocene tundra conditions in South-central Pennsylvania.- Annual Meeting of the Geological Society of America Abstracts with Programs, 34, A-27.

Duigon, M.T., 2001: Karst hydrogeology of the Hagerstown 
Valley, Maryland.- Department of the Environment, Washington County, Maryland, pp. 128.

Gathright, T.M., Henika, W.S. \& J.L. Sullivan, 1977: Geology of the Waynesboro East and Waynesboro West Quadrangles, Virginia.- Commonwealth of Virginia, Dept. of Conservation and Economic Development, Division of Mineral Resources, pp. 53.

Grote, T., 2001: Baseflow geochemistry of a fluviokarst watershed, Burd Run, south-central Pennsylvania.- MS thesis. Shippensburg University, pp. 120.

Grote, T., 2006: Late Cenozoic Stratigraphy and Landscape Dynamics in the Unglaciated Central Appalachians - A case study from the Northern Blue Ridge, South-Central Pennsylvania, USA.-PhD thesis. West Virginia University, pp. 117.

Grote, T., 2017: Surficial processes and stratigraphy of alluvial fans along the Blue Ridge-Great Valley Border, south-central Pennsylvania.- Southeastern Geology, 52, 157-177.

Grote, T. \& C.J. Woltemade, 2002: Bedrock and surficial geologic controls on baseflow chemistry in the Burd Run Watershed, south-central Pennsylvania.- Pennsylvania Geographer, 40, 101-112.

Grote, T. \& J.S. Kite, 2004: Surficial geology of the western flank of South Mountain, Washington County, Maryland; USGS EDMAP program contract \# 03HQAG0046: unpublished document.- Department of Geology and Geography, West Virginia University.

Grote, T. \& J.S. Kite, 2006: Surficial geology of the northwestern footslope of South Mountain, south-central, Pennsylvania; USGS EDMAP program contract \# 05HQAG0045: unpublished document.- Department of Geology and Geography, West Virginia University.

Gustavson, T.C., 1986: Geomorphic development of the Canadian River Valley, Texas Panhandle: An example of regional salt dissolution and subsidence.- Geological Society of America Bulletin, 97, 459-472. DOI: 10.1130/0016-7606(1986)97<459:GDOTCR> 2.0.CO;2

Heller, M.J., Hancock, G.S. \& M.W. Carter, 2014: Structure and geomorphology at the Blue Ridge-Valley and Ridge boundary near Big Levels, Virginia.- Annual Meeting of the Geological Society of America Abstracts with Programs 46, 3, pp. 12.

Kochel, R.C., 1990: Humid fans of the Appalachian Mountains.- In: Rachocki, A.H. \& M. Church, (eds.) Alluvial Fans: A field approach. John Wiley, pp. 109129, New York.

Luzon, A., Perez Garcia, A., Soriano, M.A. \& A. Pocovi, 2008: Sedimentary record of Pleistocene paleodoline evolution in the Ebro Basin (NE Spain).- Sedi- mentary Geology, 205, 1-13. DOI: 10.1016/j.sedgeo.2008.01.004

Luzon, A., Rodriquez-Lopez, J.P., Perez Garcia, A., Soriano, M.A., Gil, H. \& A. Pocovi, 2012: Karst subsidence as a control on the accumulation and preservation of Aeolian deposits: A Pleistocene example from a proglacial outwash setting, Ebro Basin, Spain.- Sedimentology, 59, 2199-2225. DOI: https:// doi.org/10.1111/j.1365-3091.2012.01341.x

Miall, A.D., 1996: The Geology of Fluvial Deposits: Sedimentary Facies, Basin Analysis and Petroleum Geology.- Springer-Verlag, pp. 582, Berlin.

Pazzaglia, F.J., Braun, D.D., Pavich, M., Bierman, P., Potter, N. Jr., Merritts, D., Walter, R. \& D. Germanoski, 2006: Rivers, glaciers, landscape evolution, and active tectonics of the central Appalachians, Pennsylvania and Maryland.- In: Pazzaglia, F.J. (ed.) Excursions in Geology and History: Field Trips in the Middle Atlantic States. Geological Society of America Field Guide 8, 169-197, Boulder. DOI: 10.1130/2006.fld008(09)

Pazzaglia, F.J., 2014: Brief thoughts on long-term landscape evolution in the Mid-Atlantic region with a focus on the Pond Bank lignite.- In: Anthony, R. (ed.) Pennsylvania's Great Valley and bordering mountains near Carlisle. Field Conference of Pennsylvania Geologists 2014 Annual Meeting Guidebook.

Pierce, K.L., 1965: Geomorphic significance of a Cretaceous deposit in the Great Valley of Southern Pennsylvania.- U.S. Geological Survey Professional Paper 525C, C152-C156.

Quinlan, J.F., 1967: Classification of karst types: A review and synthesis emphasizing the North American literature, 1941-1966.- Bulletin of the National Speleological Society, 29, 107-109.

Sauro, U., Ferrarese, F., Francese, R., Miola, A., Mozzi, P., Rondo, G.Q., Trombino, L. \& G. Valentini, 2009: Doline fills - Case study of the Faverghera Plateau (Venetian Pre-Alps, Italy).- Acta Carsologica, 38, 1, 51-63. DOI: https://doi.org/10.3986/ac.v38i1.136

Sevon, W.D., 1994: Solution below, injection within, and subsidence throughout alluvial-fan deposits, South Mountain, Pennsylvania.- Annual Meeting of the Geological Society of America, Abstracts with Programs, 26, 3, 72 .

Sevon, W.D., 2001: Landscape evolution in the Cumberland Valley, southeastern Pennsylvania.- In: Potter, N., Jr. (ed.) The geomorphic evolution of the Great Valley near Carlisle, Pennsylvania: Carlisle, Pennsylvania. Southeast Friends of the Pleistocene 2001 Annual Meeting Guidebook.

Shunk, A.J., Driese, S.G. \& G.M. Clark, 2006: Latest Miocene to earliest Pliocene sedimentation and climate 
record derived from paleosinkhole fill deposits, Gray Fossil Site, northeastern Tennessee, USA.- Palaeogeography, Palaeoclimatology, Palaeoecology, 231, 3-4, 265-278. DOI: 10.1016/j.palaeo.2005.08.001

Shunk, A.J., Driese, S.G., Farlow, J.O., Zavada, M.S. \& M.K. Zoba, 2009: Late Neogene paleoclimate and paleoenvironment reconstructions from the Pipe Creek Sinkhole, Indiana, USA.- Paleogeography, Plaeoclimatology, Paleoecology, 274, 3, 173-184. DOI: 10.1016/j.palaeo.2009.01.008

Soriano, M.A., Luzon, A., Yuste, A., Pocovi, A., Perez, A., Simon, J.L. \& H. Gil, 2012: Quaternary alluvial sinkholes: Record of environmental conditions of karst development, Examples from the Ebro Basin, Spain.- Journal of Cave and Karst Studies, 74, 2, 173-185. DOI: 10.4311/2011JCKS0201

Southworth, S., Aleinikoff, J., Bailey, C., Burton, W., Crider, E., Hackley, P. \& R. Tollo, 2009: Geologic Map of the Shenandoah National Park Region, Virginia.- U.S. Geological Survey Open-File Report 2009-1153.

Stepišnik, U., Ferk, M., Gostinčar, P., Černuta, L., Peternelj, K., Stembergar, T. \& U. Ilič, 2007: Alluvial fans of contact karst: An example from Matarsko Podolje, Slovenia.- Acta Carsologica, 36, 2, 209-215. DOI: 10.3986/ac.v36i2.189
Tschudy, R.H., 1965: An Upper Cretaceous deposit in the Appalachian Mountains.- U.S. Geological Survey Professional Paper 525-B.

Watts, W.A., 1979: Late Quaternary vegetation of central Appalachia and the New Jersey coastal plain.- Ecological Monographs, 49, 427-469. DOI: $10.2307 / 1942471$

Weissmann, G.S., Mount, J.F. \& G.E. Fogg, 2002: Glacially driven cycles in accumulation space and sequence stratigraphy of a stream-dominated alluvial fan, San Joaquin Valley, California, USA.- Journal of Sedimentary Research, 72, 2, 240-251. DOI: $10.1306 / 062201720240$

White, W.B., 1988: Geomorphology and Hydrology of Karst Terrains. Oxford University Press, pp. 464, New York. DOI: 10.1002/jqs.3390040211

White, W.B., 2009: The evolution of Appalachian fluviokarst: Competition between stream erosion, cave development, surface denudation, and tectonic uplift.- Journal of Cave and Karst Studies, 71, 3, 159167.

Whittecar, G.R. \& D.F. Duffy, 2000: Geomorphology and stratigraphy of Late Cenozoic alluvial fans, Augusta County, Virginia, USA.- Southeastern Geology, 39, 259-279. 